\title{
CRITICAL REVIEW OF SERVICE QUALITY SCALES WITH A FOCUS ON CUSTOMER SATISFACTION AND LOYALTY IN RESTAURANTS
}

\author{
Abdullah USLU ${ }^{a^{*}}$, Ramazan EREN $^{b}$ \\ a Akdeniz University, Manavgat Tourism Faculty, 07600, Manavgat, Antalya-Turkey, email: \\ auslu@akdeniz.edu.tr, Corresponding author \\ b Akdeniz University, Manavgat Tourism Faculty, 07600, Manavgat, Antalya-Turkey, email: \\ ramazaneren@akdeniz.edu.tr
}

Cite this article: Uslu, A., Eren, R. (2020). Critical review of service quality scales with a focus on customer satisfaction and loyalty in restaurants. Deturope. 12(1), 64-84.

\begin{abstract}
This study provides a critical review of the instruments developed for measuring service quality in restaurants. However, this study reviews the researches to examine the relationships between service quality, customer satisfaction (CS), and customer loyalty (CL) in restaurants. It is revealed that there are many attempts to develop instruments that aim to measure service quality in restaurants. SERVQUAL instrument, which measures service quality (SQ), has been used in many studies related to the tourism industry. However, the SERVQUAL is directly used as the basis of the SERVPERF and DINESERV instruments. Besides, since the GRSERV and CFFRSERV scales are based on DINESERV, the SERVQUAL plays an important role in the development of such scales. In addition to the instruments developed by modifying SERVQUAL, there are attempts to create different ones. In researches that develop a new SQ scale, the reasons underlying this need are stated as follows: 1) Some service quality components specific to restaurants and tourism sector not included in the current scales 2) Measuring the expectations and performance at the same time is not necessary 3) Current scales are insufficient for the unique types of restaurants, such as Fast Food, Upscale and Green Restaurants. CS and CL are the most common variables in the studies examining the SQ in restaurants. There is a divergence in the literature about whether service quality leads to satisfaction or satisfaction brings service quality. However, it can be said that there is a consensus that these two structures are in a very close relationship with each other. Another consensus in the literature is that CS and SQ are regarded as the determinants of CL. On the other hand, a considerable amount of research has been devoted to service quality, customer satisfaction, and customer loyalty, and it will be the case for future studies. However, the changes in business environments reveal the necessity of modification in the instruments that will pave the way to measure these concepts. A pandemic has recently affected the lives of businesses, and people and this new situation may require the addition of a new dimension to service quality instruments, like outbreak measures.
\end{abstract}

Keywords: Service Quality Scales, Customer satisfaction, Customer loyalty, critical review, restaurants.

\section{INTRODUCTION}

Different types of businesses in the hospitality, and food and beverage industry trying to deliver their products and services in a competitive environment but also gain an advantage with customer satisfaction and increased loyalty. Businesses adopt different marketing strategies (Namin, 2017) to offer products with high quality for satisfied customers (Shemwell, Yavas, \& Bilgin, 1998). Service quality and customer satisfaction are two important concepts addressed 
in marketing theories and studies. Satisfaction refers to "a judgment that a product or service feature, or the product or service itself, provided (or is providing) a pleasurable level of consumption fulfillment, including the levels of under or over fulfillment" (Oliver, 1997:13).

Foodservice and customer satisfaction can be evaluated through a range of factors such as food quality (Fanelli \& Di Nocera, 2018), hygiene, service quality (Taylor \& Baker, 1994), and atmosphere (Yüksel \& Yüksel, 2003). The overall dining experience in a restaurant is used to conceptualize customer satisfaction by way of assessing both food quality and service quality (Alhelalat, Habiballah, \& Twaissi, 2017; Kaya, 2018).

The service quality is such a factor that affects the satisfaction of the customers (Löke, Kovács, \& Bacsi, 2018) and their re-visit intentions (Eren, 2019). Mattila, (2001) puts forward 3 elements affecting the customers' restaurant preferences as follows: service, food quality, and atmosphere. Properly organized food service may increase the service quality perception of the restaurant and have a positive effect on customer satisfaction and behavioral intentions (Choe \& Kim, 2018; Ryu \& Han, 2010).

Customer satisfaction, on the other hand, is one of the fundamental constructs used to explain the process of establishing customer loyalty (Brida \& Coletti, 2012; Brunner, Stöcklin, \& Opwis, 2008; Han \& Hyun, 2018; Ostrowski, O’Brien, \& Gordon, 1993). Similarly, reviewing the studies on customer satisfaction and customer loyalty in literature, it is observed that customer satisfaction affects customer loyalty positively (Bolton \& Lemon, 1999; Dick \& Basu, 1994; Oliver \& Burke, 1999).

Customer loyalty is considered as a repetitive behavior which results from psychological decision-making and evaluation processes and is driven by positive behaviors (Jacoby \& Kyner, 1973). It is seen that different scales and different attitudinal and behavioral approaches are used to measure customer loyalty (Oliver \& Burke, 1999; Zeithaml, 2000). Those who discuss the subject from the attitudinal perspective consider customer loyalty a special desire to maintain a relationship with a service provider.

From the behavioral perspective, customer loyalty is characterized by repeat customers, and it refers to a customer's purchasing the same product or service in a specific category much more than the total number of purchases made by other customers in the same category (Neal, 1999). Loyal customers bring great advantages to organizations by providing constant profit flow and decrease marketing/promotion costs. Increasing and maintaining the number of loyal customers is in the center of the firm's long-term success (TaghiPourian \& Bakhsh, 2015). A highly loyal customer repeatedly purchases a product/service and possesses a positive sense of attitudinal loyalty toward the brand (Pritchard \& Howard, 1997). 
Customer satisfaction and customer loyalty have been studied by many researchers in travel, tourism, and F\&B industries (Back \& Parks, 2003; W. Kim, Ok, \& Canter, 2010; Pizam \& Ellis, 1999; Yüksel \& Yüksel, 2003). In the study conducted by Line and Runyan (2012: 478-479), it was concluded that satisfaction as the subject was discussed in $8.8 \%$ of the studies in total, taking into consideration 278 marketing-oriented researches published between 2008 and 2010 in four leading journals (Cornell Hospitality Quarterly, International Journal of Hospitality Management, Journal of Hospitality \& Tourism Research, International Journal of Contemporary Hospitality Management). In this period for the studies mentioned above, satisfaction was the most studied subject. On the other hand, the subject of loyalty was discussed in $\% 3.6$ of the studies in total. $31.7 \%$ of 278 studies in total in the tourism industry focus on restaurants, which is the second most studied subject field after hotels. Another striking point in Line \& Runyan, (2012)'s study is that $88 \%$ of the papers on satisfaction are about restaurants.

\section{METHODOLOGY}

This study aims to review critically (1) the main service quality measurement scales and (2) how these scales used in researches to examine the relationship between service quality (SQ), customer satisfaction (CS), and customer loyalty (CL) in restaurants.

For the first part of the study review required studies to be focused on the development of SQ scales for restaurants that follow the methodological steps (1) Item development, theoretical frameworks on the service quality, empirical investigations, or panels of experts (2) Reliability and Validity analysis.

For the second part of the review to identify studies the inclusion criteria was to examine the relationships between SQ, CS, and CL in restaurants. There was one exclusion criteria for both of the parts: the electronic service quality or e-service quality (mainly services provided in digital platforms) researches.

To collect the relevant literature on SQ scale development, and CS and CL the following search terms in title, keywords, or abstracts were used: "Service quality measurements" "service quality scale restaurants" "Tools of service quality in restaurants" "service quality measurement in restaurants". The relevant literature was sought in the most significant electronic databases for tourism: Web of Science and Scopus. The articles were screened for inclusion and exclusion criteria after completing the literature search. 


\section{LITERATURE REVIEW}

The number of restaurants like the other businesses in the food and beverage industry in the world has increased in the last 20-30 years and the world population spends remarkable time in these establishments apart from the basic living spaces such as workplace, and home (Antun et al., 2010). In order to respond to the demand, it has become inevitable for restaurants to offer a wide range of products and services to increase the value in customers and distinguish the business from its competitors. It will be possible for restaurants to increase the quality of their services by way of determining and fulfilling the factors affecting restaurant preferences of customers, and thus, their satisfaction and loyalty

Success in the food and beverage industry and customer satisfaction (CS) is directly linked to service quality (SQ). There are different perspectives about the dimensions of SQ and linkage between these two constructs. Disagreement on the proposed association between SQ and satisfaction has led to a split over causality, with one side supporting the proposal that quality leads to satisfaction (Woodside, Frey, \& Daly, 1989) and the other side supporting the proposal that satisfaction leads to SQ (Bitner, 1990). Cronin and Taylor (1992) concluded that the quality of service can be seen as a determinant of satisfaction, in this wise affects consumer loyalty (Asubonteng, Mccleary, \& Swan, 1996). Besides, Heskett et al., (1994) defined SQ as a critical component of customer loyalty. Beyond the disagreement for the relationships, this study firstly focuses on the SQ issue and its measurement instruments for restaurants.

\section{Instruments for measuring service quality in restaurants}

In the $1980 \mathrm{~s}$ and $1990 \mathrm{~s}$, the number of researches related to perceived service quality increased due to the research gap of measuring and defining the construct. One of the most important contributions to SQ literature has been done by Parasuraman et al., (1985) which defined service quality as "a function of the differences between expectation and performance along the quality dimensions". Parasuraman et al. (1985) indicated that the SQ is a result of the variations between expectations and results in terms of quality. They have developed a SQ model based on a gap analysis that identifies SQ as a function of perception and expectations. Parasuraman et al. (1985) in their first attempt used ten dimensions to measure but they refined the subsequent measurement tool named SERVQUAL with the research Parasuraman et al., (1988) and the original dimensions changed to five dimensions with 22 items. These dimensions include tangibles, reliability, responsiveness, assurance, and empathy (the difference of the first version: communication, competence, credibility, courtesy, and security). Parasuraman et al., (1988) defined SQ as "the degree and direction of discrepancy between consumers' perceptions and expectations". SQ can be measured with the gap between a customer's expectations and the 
perceptions of what is actually delivered (H. Qin \& Prybutok, 2009). Before the SERVQUAL instrument, the idea of a gap model has already used by Grönroos, (1984) as a concept about service quality. SERVQUAL instrument used by different researchers to measure SQ in restaurants (Bojanic \& Drew Rosen, 1994; Fick \& Brent Ritchie, 1991; Fu \& Parks, 2001; Lee \& Hing, 1995; Nam \& Lee, 2011; Tzeng \& Chang, 2011).

After the development of SERVQUAL instrument, a debate discussed between academics about the adequacy of the scale to measure SQ (Brown, Churchill, \& Peter, 1993; Cronin \& Taylor, 1992, 1994; Dabholkar, Shepherd, \& Thorpe, 2000; Teas, 1993). Differentiation of ideas was about the "expectations-performance gap as the basis for measuring service quality" (Cronin and Taylor, 1992, p. 56) and the reliability and validity of dimensions. Cronin and Taylor, (1992) examined the measurement of SQ and the relationship between SQ, CS, and purchase intention. This research discarded the expectations portion of SERVQUAL instrument and just used the performance indicators in the new scale named as "SERVPERF" that originated from "performance-only measures". The new approach prefers to use consumers' perceptions of the performance of the service provider to measure SQ, rather than using the difference between expectations and performance perceptions of customers (Seth, Deshmukh, \& Vrat, 2005). In addition to their theoretical contribution, Cronin and Taylor (1992) used SERVPERF instrument for different industries including fast-food restaurants. The dimensions used in SERVPERF instrument same as SERVQUAL dimensions and namely tangibility, reliability, responsiveness, assurance, and empathy. SERVPERF has been used to measure SQ in restaurants in different researches (Namin, 2017; G. Qin \& Prybutok, 2008; H. Qin, Prybutok, \& Peak, 2009; Ramseook-Munhurrun, 2012; Yesiltas, Zorlu, Sop, \& Beydilli, 2014). Qin \& Prybutok, (2009) used SERVPERF instrument to measure SQ in restaurants and employed a new dimension namely recovery.

Another attempt to develop a scale to measure SQ made by Knutson et al., (1996) and Stevens et al., (1995). The authors introduced DINESERV instrument in 1995 to measure service quality in restaurants. This new instrument as a questionnaire consists of 29 items and uses five dimensions namely; assurance, empathy, reliability, responsiveness, and tangible (Hansen, 2014). DINESERV was developed with reference to LODGSERV (lodging service) and SERVQUAL. Stevens et al. (1995) emphasize that customers seek restaurants that can meet their quality and value standards. From that point, restaurants need DINESERV instrument to learn about how customers perceive SQ in the restaurant. DINESERV also gives more information to restaurateurs about customers' expectations. DINESERV instrument has been used by different researches for restaurants (eg. Bougoure \& Neu, 2010; H. J. Kim et al., 2003; W. G. Kim et al., 2009). 
Table 1 Scales Used to Measure Service Quality in Restaurants

\begin{tabular}{|c|c|c|c|}
\hline Publication & $\begin{array}{l}\text { Name of the } \\
\text { Scale }\end{array}$ & $\begin{array}{l}\text { Number of } \\
\text { Items }\end{array}$ & Dimensions \\
\hline $\begin{array}{l}\text { Parasuraman et } \\
\text { al. }(1985,1988, \\
\text { 1991) }\end{array}$ & SERVQUAL & $\begin{array}{l}22 \text { items on } \\
\text { expectation, } \\
22 \text { items on } \\
\text { perception }\end{array}$ & $\begin{array}{l}\text { SERVQUAL scale measures the service } \\
\text { quality in } 5 \text { dimensions in all kinds of } \\
\text { service enterprises: tangibles, reliability, } \\
\text { responsiveness, assurance, empathy. }\end{array}$ \\
\hline $\begin{array}{l}\text { Cronin \& Taylor, } \\
\quad(1992,1994)\end{array}$ & SERVPERF & $\begin{array}{l}22 \text { items on } \\
\text { perception }\end{array}$ & $\begin{array}{l}22 \text { perception-related items in SERVQUAL } \\
\text { are used. It emerged as an alternative } \\
\text { technique to SERVQUAL. It is composed of } \\
5 \text { dimensions as follows: tangibles, } \\
\text { reliability, responsiveness, assurance, and } \\
\text { empathy. }\end{array}$ \\
\hline $\begin{array}{l}\text { Stevens et al. } \\
\quad(1995)\end{array}$ & DINESERV & 29 items & $\begin{array}{l}\text { This scale was adapted from SERVQUAL } \\
\text { for restaurant enterprises. Expectation and } \\
\text { satisfaction dimensions are measured } \\
\text { separately. It is composed of } 5 \text { dimensions } \\
\text { as follows: material elements, reliability, } \\
\text { responsiveness, assurance, and empathy. }\end{array}$ \\
\hline $\begin{array}{l}\text { Antun et al. } \\
\text { (2010) }\end{array}$ & DINEX & 20 items & $\begin{array}{l}\text { It is composed of } 5 \text { dimensions as follows: } \\
\text { food, service, atmosphere, social, and health. }\end{array}$ \\
\hline $\begin{array}{l}\text { Ryu \& Shawn } \\
\text { Jang, (2008) }\end{array}$ & DINESCAPE & 21 items & $\begin{array}{l}\text { It is composed of } 6 \text { dimensions as follows: } \\
\text { facility aesthetics, ambiance, lighting, table } \\
\text { settings, layout, and service staff. The most } \\
\text { important dimensions are ambiance, service } \\
\text { staff, and facility aesthetics. }\end{array}$ \\
\hline Raajpoot (2002) & TANGSERV & 13 items & $\begin{array}{l}\text { It is composed of } 3 \text { dimensions. It aims at } \\
\text { measuring particularly the tangible/physical } \\
\text { elements. The dimensions are layout/design, } \\
\text { product/service, and ambiance/social. }\end{array}$ \\
\hline $\begin{array}{l}\text { Kivela et al. } \\
(1999 ; 2000)\end{array}$ & $\begin{array}{l}\text { Dining } \\
\text { Satisfaction }\end{array}$ & 28 items & $\begin{array}{l}\text { It is composed of } 5 \text { dimensions as follows: } \\
\text { food, service, atmosphere, suitability, and } \\
\text { "A restaurant... (Experience)" }\end{array}$ \\
\hline Chen et al. (2015) & GRSERV & 28 items & $\begin{array}{l}\text { It is composed of } 7 \text { dimensions. The } \\
\text { dimensions are tangibles, reliability, } \\
\text { responsiveness, assurance, empathy, } \\
\text { environment-focused services, and food } \\
\text { quality. }\end{array}$ \\
\hline $\begin{array}{l}\text { Tan, Oriade \& } \\
\text { Fallon }(2014)\end{array}$ & CFFRSERV & 28 items & $\begin{array}{l}\text { The scale uses } 28 \text { items under six } \\
\text { dimensions namely; tangibles, cleanliness, } \\
\text { food quality, responsiveness, reliability \& } \\
\text { assurance, and empathy. }\end{array}$ \\
\hline
\end{tabular}

Source: own elaboration from literature.

Antun et al., (2010) used various quantitative and qualitative methods in their study to develop DINEX scale. The items in the scale were developed by applying the Delphi method on small groups of professional restaurant managers and owners. The main goal of the Delphi method is to obtain the most eligible and detailed data. In order to clarify and highlight the scale 
items, focus group interviews were conducted. Out of 6 focus groups in total, 3 groups were made up of restaurant professionals while the other 3 groups were composed of restaurant customers. As a result of the focus group interviews, the scale items were clearly put forward. The number of the scale items was reduced by the pre-test stage. As a result of factor analysis (explanatory and confirmatory), DINEX scale items became final in a way to consisting of 5 dimensions (food, service, atmosphere, social dependency, and health) and 20 items.

DINEX is a scale that can make all calculations while taking into a consideration dining experience and the most important expectations of customers' which are in reciprocal interaction within a completely complex structure. DINEX scale's greatest contribution to the literature is that it involves new dimensions namely social and health (Antun et al. 2010).

Similar to Antun et al. (2010), Kivela, Reece, and Inbakaran (1999) also benefited from the Delphi method throughout the scale development process. "Dining Satisfaction" was developed in order to measure the satisfaction in full-service restaurants offering a la carte service rather than measuring the satisfaction in fast-food restaurants. For the development of the scale, relevant individuals such as restaurant managers and potential customers were interviewed in groups. In addition, three different group interviews were carried out with these groups in three stages, and a scale construct consisting of 5 dimensions (food, service, atmosphere, suitability, experience) and 28 items was developed finally.

Ryu \& (Shawn) Jang, (2008) used quantitative analyses to develop the DINESCAPE instrument and aimed to fulfill research gaps about customer perceptions of physical environments in restaurants, especially in the upscale restaurants. Researchers identified physical environment dimensions for upscale restaurants namely; facility aesthetics, ambiance, lighting, table settings, layout, and service staff. The name DINESCAPE was inspired from to SERVICESCAPE instrument but it is different because DINESCAPE does not contain external environments (e.g., parking and external building design) and non-dining internal environments (e.g., restroom and waiting area). Ryu \& (Shawn) Jang, (2008) defined the DINESCAPE as a measurement tool for "the man-made physical and human surroundings in the dining area of restaurants". Due to the target businesses (upscale restaurants), researchers stated that this instrument can be modified for more suitable measurement purposes for different restaurant segments.

Later than other researches Raajpoot, (2002) proposed a new instrument called TANGSERV to measure the tangible qualities in the business of the foodservice industry. This relatively new instrument contains ambient/social factors (e.g., music and temperature), layout/design factors (e.g., location and seating arrangement), and product/service factors (e.g., food presentation). Academia did not pay much attention to this instrument. The importance of TANGSERV 
instrument for the literature was the attempt to put forward social factors such as employee behavior, customer compatibility, and crowding. Social factors can be noteworthy for customers and can affect the perceived SQ in a restaurant. One of the author's starting points is the lack of some ambient factors in SERVQUAL and DINESERV such as music, light, and temperature.

Kivela et al., (2000); Kivela, Inbakaran, et al., (1999); Kivela, Reece, et al., (1999) conducted three researches to develop a scale for SQ in restaurants. Authors published the results of the process in three different articles. Authors prepared theoretical background in the first part, in the second part they implemented scale development process and in the third part, they used the scale to measure SQ in Hong Kong restaurants. Authors used the Delphi technique and conducted three semi-structured face-to-face interviews to develop the instrument.

The first section of the questionnaire asks participants the expectations and importance of the attributes when the participants decide to dine in the restaurant. In the second section the same attributes used for measuring if the restaurant meets with expectations of participants. The instrument involves 28 restaurant attributes measured on a weight matrix scale ranging from 1 to 5 (E part: Low E. to High E.; I part Not I. to Very I.; EM part: Not ME to Has ME) listed under five factors. (1. food factors; 2. service factors; 3. ambiance factors; 4. convenience factors; and 5 a restaurant that offers). With the three parts (two sections) of the instrument authors firstly measure Expectations" (E), "Importance" (I), "Expectations met" (EM) and then pre-dining perceptions \pm "PrDp" (ExI) and post-dining perceptions \pm "PoDp" (EMxI) are calculated.

In the restaurant service quality literature an important contribution is GRSERV scale which was organized for green restaurants. Chen et al., (2015) used qualitative and quantitative procedures to develop, and test reliability of Green Restaurant Service Quality scale (GRSERV). As Chen et al., (2015) used in their study, a green restaurant refers to one that offers a selection of green food items using locally grown or certified established food, as well as one that implements green practices such as a recycling program, energy and water efficiency, and solid waste reduction. Authors' criticism for past scales was the failure to propose a scale applicable to assets SQ in green restaurants.

Researchers used the DINESERV scale as the basis to develop the GRSERV. There are 28 items in GRSERV under 7 dimensions namely tangible, reliability, responsiveness, assurance, empathy, environmental- oriented services, and food quality. GRSERV brings two new dimensions apart from DINESERV to measure SQ. Items of DINESERV revised for GRSERV due to the service characteristics and green practices of green restaurants. 
Tan et al., (2014) developed a new scale (CFFRSERV=Chinese Fast food restaurants service quality scale) for measuring quality of services in fast food restaurants' by modifying DINESERV scale. This new scale included twenty-eight items under six dimensions namely; tangibles, cleanliness, food quality, responsiveness, reliability \& assurance, and empathy. Authors' criticism for DINESERV instrument is the cultural differences and they stated that it was developed based on the American cultural elements. The generalizability of DINESERV to other cultures so countries is questionable and CFFRSERV with the Chinese context can measure SQ effectively in Chinese fast-food restaurants.

\section{Determinants of Customer Satisfaction and Customer Loyalty for Restaurants}

Examining the studies in the literature, it is generally observed that the dimensions of satisfaction are food, atmosphere, service, and social factors (friendship, social dependency, etc.). Similarly, the dimensions of loyalty are discussed in two dimensions as behavioral intentions and customer share of visits. However, behavioral intentions embody the re-visiting intention, positive word of mouth advertising, and recommendation.

Table 2 Determinants of satisfaction and loyalty

\begin{tabular}{|c|c|c|}
\hline Publication & $\begin{array}{c}\text { Determinants } \\
\text { (Dependent Variable) }\end{array}$ & $\begin{array}{c}\text { Satisfaction/Loyalty } \\
\text { (Independent Variable) }\end{array}$ \\
\hline Weiss et al. (2004) & $\begin{array}{l}\text { Food quality, Service quality, } \\
\text { Atmosphere, and Innovation }\end{array}$ & Satisfaction \\
\hline Ryu \& Han (2011) & $\begin{array}{c}\text { Environmental factors, } \\
\text { Disconfirmation (Positive- } \\
\text { Neutral-Negative) }\end{array}$ & Satisfaction and Revisit \\
\hline Liu \& Jang (2009) & $\begin{array}{c}\text { Environmental factors, } \\
\text { Perceived value, Emotional } \\
\text { Responses }\end{array}$ & Revisit \\
\hline Han et al. (2009) & $\begin{array}{l}\text { Satisfaction and Consumption } \\
\text { Feelings }\end{array}$ & Loyalty \\
\hline Antun et al. (2010) & Social bonds & Satisfaction and Revisit \\
\hline $\begin{array}{l}\text { Sulek \& Hensley } \\
\text { (2004) }\end{array}$ & $\begin{array}{l}\text { Food, Atmosphere, and } \\
\text { Fairness of wait }\end{array}$ & Loyalty \\
\hline Han et al. (2009) & Switching barriers, Emotions & Satisfaction and Revisit \\
\hline Kim et al. (2010) & $\begin{array}{c}\text { Switching cost (Procedural, } \\
\text { Social and Lost benefit), } \\
\text { Emotions }\end{array}$ & $\begin{array}{c}\text { Satisfaction and Customer share of } \\
\text { visits }\end{array}$ \\
\hline Han et al. (2009) & $\begin{array}{c}\text { Brand preference, Internal drive } \\
\text { for variety-seeking, Diversity in } \\
\text { alternatives }\end{array}$ & Loyalty \\
\hline $\begin{array}{l}\text { Kivela et al. (1999a) } \\
\text { (1999b) }\end{array}$ & Importance attached & Satisfaction \\
\hline
\end{tabular}

Source: own elaboration from literature. 
When Tab. 2 is analyzed from a generic perspective, it is seen in each study that the researchers put forward particular determinants of satisfaction and loyalty. To address them in an integrated framework, the determinants of satisfaction can be listed as follows: sociodemographic variables, environmental factors, perceived value (hedonic and utilitarian values), the fairness of wait time, consumption feelings, interaction with service personnel and interaction with other customers. On the other hand, the determinants of loyalty are listed as perceived value, switching costs, attractiveness of alternatives, internal drive for varietyseeking, and atmosphere.

According to Oliver, (1980) customer satisfaction is an outcome resulting from customers' comparing their expectations of service and the perceived performance of the product. On the other hand, loyalty is defined as the image of revisit intention or the action of revisiting or not visiting. Furthermore, the customer share of visits is also considered within the scope of loyalty.

Customer loyalty and customer satisfaction are two parallel issues in the literature. Loyalty is the result of a consumer's constant satisfaction with a product to which $\mathrm{s} /$ he attaches importance. Customer loyalty provides an opportunity for businesses to re-sell and brings stability to the market. Market stability is a condition created by satisfied customers (Marangoz \& Akyıld1z, 2007:200)

In order to better assess customer satisfaction, we need to understand the disconfirmation model. In this context, customers purchase a product with an expectation of the product performance when used. The expected result creates satisfaction. What underlies the satisfaction is the comparison between the expectations about a specific product or service and the actual performance of the product or service in question. Perceived performance may satisfy, go beyond or fall short of the expectations. As a result of the process, it may elevate or reduce the re-purchase intentions on the product or service.

In brief, while positive disconfirmation arises when the performance of a product or service exceeds the expectations, negative disconfirmation emerges in the opposite case. In case that expectations and performance are equal, neutral disconfirmation, which is a positive confirmation, occurs.

Almost in every study on customer satisfaction in restaurants, the possibility to predict the re-purchase action is primarily associated with the dimension of food quality. It is argued that the food quality is the most important determinant factor in ensuring customer loyalty. Similarly, one of the important factors to evaluate customer satisfaction in restaurant enterprises is service quality. Also, atmosphere is another important factor regarding the revisits by repeat customers. Atmosphere includes decoration, music, lighting, and so on. In conclusion, food 
and drink quality, service quality and atmosphere are the main factors affecting customer satisfaction.

According to the results of Weiss et al., (2004)'s study, it is seen that the matters from which customers experienced the highest satisfaction were, respectively, hygiene of the restaurant, effective service and food quality whereas a new dining experience brought along the lowest level of satisfaction. In the study carried out in theme restaurants, it was observed that innovation was less effective than the other determinants of satisfaction. Restaurant managers and business owners should focus on other dimensions rather than the innovation dimension only. It was concluded that innovation did not play an important role in loyalty whereas the food quality and atmosphere had remarkable effects.

Although there exist numerous studies in the literature on what the expectation of restaurant customers are, the results are inadequate since the subject has been examined from very limited perspectives. Hence, commonly accepted factors on satisfaction and loyalty could not be put forward. However, the underlying cause is the challenging nature of the dining experience (Antun et al. 2010).

In the study by Weiss et al., (2004) quality of restaurants, food quality, and atmosphere were discussed; however, social aspects of dining experience were ignored to a great extent. Dining experience in restaurants satisfies the social needs of customers. In the study by (Rosenbaum, 2006), it was discovered that friendship and social bonds of customers had a positive effect on the re-purchase and loyalty. Individuals will prefer the same restaurant on the condition that they have a social network and friendships there. The social dependency tendency originates from homophily (tendency towards similar ones).

Restaurants must find out the actual expectations of customers to satisfy and motive them to revisit. Not only the food, service, and atmosphere quality but also the social aspects of dining experience should be explored and taken into notice. In literature, it is quite difficult to explain these three constructs. The subject of food is about the presentation of food. Food quality, on the other hand, can be considered within the scope of food safety and the fact that it pleases the customer. Nevertheless, in the light of this definition, unhealthiness of food can be discussed as a different construct.

The quality of the restaurant atmosphere embodies a multidimensional structure. These dimensions are the atmosphere of dining places, comfort of the decoration, lighting, hygiene, temperature, scent, and music. The restaurant atmosphere includes social components, as well. Within a social framework, social dependency is related to intrinsic feelings and it guides individual emotions, ideas, and behaviors. Individuals develop social dependency emotions in 
interaction with family, partners, acquaintances, strangers, community, and society (Antun et al. 2010).

Homophily (the concept of similarity) facilitates the functioning of social dependency. It depends on the idea that the perception of an individual is similar to the perception of another individual. In the context of the perceived similarity; if specific attributes such as value, belief, education, and social status are similar in similar reciprocal periods, a tendency to similarities is observed. Measurement factors of perceived similarity are attitude, history, ethics, and appearance. In the scope of the measurements on attitude, it is seen that social class, economic status, and position are in the background of what type of individuals think and behave similarly. Most people act collectively and maintain this behavior for a long time. Their behaviors affect each other. They are affected more by the collective behaviors and attitudes, compared to the behavior and attitudes they perform on their own (Antun et al. 2010).

The service is consumed in a wide variety of ways. The hedonistic aspect of consumer behavior is based on consumption experience and reflects the need for entertainment and emotional value. Utilitarian consumption by nature is task-related, or functional (Ryu \& Han, 2011).

The physical environment is an important determinant of customer satisfaction and revisit. Customers may enjoy the dining experience for a longer time if they are affected by the atmosphere (Liu \& Jang, 2009; Ryu \& Han, 2011). They do it consciously or non-consciously. Food, service, a satisfying physical environment, for instance, a renovated interior design and décor, pleasant music, dim light, a unique color plan, pleasant scent, a spacious layout, a pleasant table setting, and an attractive service employee affect customer satisfaction and loyalty significantly.

The physical environment has a strong influence on hedonistic services. It is observed that different parts of the physical environment are perceived differently by the first comers and repeaters, and it is observed that there are no studies in the literature that discuss the importance of such difference (Ryu \& Han, 2011).

The Mehrabian Russell model, on the other hand, is one of the most powerful models used to explain the impact of physical environment on human behavior. Physical environment can affect an individual's emotional expressions (Liu \& Jang, 2009). Satisfaction is considered as a cognitive expression. However, a clear cognitive, namely, the logical approach is insufficient, and for a better understanding of the term, satisfaction should be examined based on emotional elements and within the context of physical environment. In order to understand customer satisfaction in luxurious restaurant enterprises, an emotional perspective should be adopted, and 
it should be realized that customer responses mostly result from emotional and hedonist consumption.

Many studies such as (Enrique Bigné, Mattila, \& Andreu, 2008; Patterson, 2007; Pizam \& Milman, 1993; Wirtz \& Bateson, 1999) conclude that disconfirmation affects customer satisfaction and customer loyalty (Ryu \& Han, 2011). Similarly, Loureiro, (2010) indicate in their study that satisfaction is an important determinant of loyalty. It has been observed that positive disconfirmation affects customer satisfaction and loyalty positively, and it is generally argued in the literature that satisfied customers maintain their loyalty to the enterprise.

Perceived disconfirmation affects customer satisfaction and customer loyalty. Positive disconfirmation is a strong determinant of customer loyalty. Disconfirmation is important for both first comers and repeaters. Factors that affect satisfaction can be listed as atmosphere, wait time, hedonistic feelings, service encounter, emotions, food-related personality traits (neophobia, brand preference, etc.). It is seen that positive and negative emotions affect the revisit intentions of customers after the dining experience. Positive emotions are important for the recognition of perceived value (Liu \& Jang, 2009).

Atmosphere has tangible and intangible features. Bitner discussed atmosphere in 3 dimensions, which are environmental conditions (lighting, temperature, music, and scent), place layout, and functionality (Liu \& Jang, 2009). Atmospheric factors do affect customers' positive and negative emotions.

Emotional response is effective in behavioral intentions. In many studies, positive emotional responses were found to be the most important determinant of behavioral intention. Pleasant and stimulant effects affect behavioral intention significantly. Negative words of mouth have also an impact on behavioral intention. Accordingly, anger, disappointment, regret, and negative word of mouth may alter the decision (Liu \& Jang, 2009).

In literature, perceived value is defined as a critical construct to develop a long-term relationship with the customer. Similarly, in another definition, perceived value is described as an outcome of perceived benefit and sacrifice resulting from the cognitive comparison. If the customers believe that the product or service is worth the money spent, they feel satisfied and intend to revisit the place. While perceived value has a direct effect on behavioral intention, it affects satisfaction indirectly. It was found that perceived value plays a mediating role in emotions and behavioral intention, and it has an important effect (Liu \& Jang, 2009).

According to Han et al. (2009), the major determinants affecting the revisiting intention of customers are satisfaction and consumption emotion. Multiple dimensions of emotions are used to explain customer behaviors. On the other hand, consumption emotions are not similar to emotional responses. Consumption emotion is less severe, more specific, and narrower in its 
scope. Satisfaction plays a mediating role between consumption emotions and the revisit intention.

Switching barriers are the factors that prevent customers from leaving when they think of switching the restaurants. Switching costs have positive and negative forms. While a good relationship with the service provider is a positive switching barrier, no alternative place is the negative switching barrier (Han, Back, \& Barrett, 2009).

Unsatisfied customers do not always change the restaurants because the switching cost is an important restrictive factor. Switching costs are very high. Lack of alternative places and high competition may lead the customer to stay in the restaurant. Han et al. (2009) put forward 4 switching barriers. 2 of them are positive and 2 of them are negative switching barriers.

1) Preference (Personal preference of food/menu)

2) Switching price (value in cash)

3) Relational benefits (interest benefits, social and private behavioral benefit)

4) Lack of alternatives

It is seen that social switching costs, lost benefits costs, procedural costs, and intrinsic inertia have a direct effect on customer share of visits (Kim et al. 2010). Enterprises that succeed in understanding the re-purchase intentions of customers will survive. Switching costs should be under control, and enterprises should develop their market strategies accordingly. According to Kim et al., (2010) there are 3 types of switching costs: Procedural costs (time, effort, difficulty, adaptation cost), social switching costs (breaking up the friendship with a service provider), benefit cost (special treatment).

Intrinsic inertia is the state of inner laziness, lack of energy, and taking no action. Another potential intrinsic factor related to customers is customer dependency and perceived brand heterogeneousness. Customers prefer one brand rather than many brands and avoid confusion (Kim et al., 2010).

According to Oh, (2000), there is a strong relationship between customer satisfaction and loyalty. The relationship between satisfaction and loyalty grows even stronger when low switching costs take over a mediating role.

Han et al., (2009) have concluded that various components of consumption emotions affect customer satisfaction; that satisfaction has a mediating effect on emotional factors in the context of the revisit intention, and that low switching barriers have a stronger effect than high switching barriers on the relationship between satisfaction and the revisit intention.

According to Liu \& Jang, (2009)'s study, disconfirmation directly affects satisfaction and loyalty. According to Kivela et al., (2000), customers in high-end restaurants feel satisfied as 
much as they are given importance. A high level of satisfaction in line with the importance attached to restaurant customers brings along the revisit intention.

\section{CONCLUSION}

Theoretical implications in our study are as follows: 1) There are mediating factors between satisfaction and loyalty. 2) There is a strong relationship between expectancy disconfirmation and satisfaction. 3) Disconfirmation plays a mediating role between satisfaction and loyalty. 4) It is seen that satisfaction is a determinant of behavioral intentions. 5) Switching costs play a mitigating role between satisfaction and revisit.

Contribution of the current study for practitioners will be ensured as a result of the development of recommendations regarding the factors to be taken into consideration by restaurant managers in order to improve customer satisfaction and loyalty. Implications put forward by the current study in accordance with the findings in the literature are important for restaurant managers and professionals.

Today, the food and beverage industry, as in all industries, is affected by the rapid change and competition in the national and international markets. The intense competition among the restaurant enterprises has rendered inevitable to establish much stronger relationships with customers in order to survive in the market and increase the market share. Restaurants which are aware of this situation should try to increase the number of activities aiming at customer satisfaction which is of vital importance for marketing activities, and they should do their best to assure loyal customers.

In the studies aimed at measuring the service quality in restaurant enterprises, food quality has always been an important dimension. The long-lasting survival of restaurant enterprises is closely related to the ability to well-know about the customers and their changing demands and to satisfy them, accordingly. In the food and beverage industry, restaurants have to increase the quality to gain a competitive advantage. To increase quality is possible to the extent you measure it. The necessity of the measurement of the service quality in restaurant enterprises has become an undeniable fact.

Due to the importance of SQ for the restaurant sector, it has been examined in many researches and many tools have been developed to measure. As a result of this research, which performs a critical review of the instruments, it has been revealed that the SERVQUAL instrument is the basis for many of them. Due to the differentiating features of restaurants from other service businesses, researches need to develop new scales to measure SQ correctly in 
restaurants. In addition, different service quality scales have been developed for different types of restaurants.

In the future researches, different SQ instruments can be developed for restaurants. Changes occurring in the industry and businesses seem to be the most important reason for this need. It is also inevitable to modify currents ones for different cultures and different types of restaurants. Digitalization in restaurant services (e.g. online reservations, mobile application menus, fast food order screens) changes the content of the service provided, and also factors such as epidemic diseases (Covid-19, SARS, MERS, etc.) will change the dimensions SQ in the restaurants.

In order to ensure customer satisfaction, enterprises should identify the customer expectations accurately, develop the products and services in line with customer expectations, investigate how customers perceive the products and services, and endeavor to have the customers perceive the organizational image positively. Furthermore, customer satisfaction on its own may be insufficient in today's competitive environment. As a matter of fact, enterprises can grow by way of retaining their customers and gaining new customers. The key for the success in restaurants is to design the restaurants in line with customers' expectations of social and physical environment, which will drive them to revisit the enterprise. However, it should be kept in mind that the revisit behavior is not always driven by satisfaction. Unsatisfied customers may revisit, as well.

Consequently, the level of customer loyalty is increased by customer satisfaction. Increased customer loyalty brings along an increase in sales, personnel satisfaction, reduced costs, and incorporation of customers into marketing and production processes.

\section{REFERENCES}

Alhelalat, J. A., Habiballah, M. A., \& Twaissi, N. M. (2017). The impact of personal and functional aspects of restaurant employee service behaviour on customer satisfaction. International Journal of Hospitality Management, 66, 46-53. https://doi.org/10.1016/j.ijhm.2017.07.001

Antun, J. M., Frash, R. E., Costen, W., \& Runyan, R. C. (2010). Accurately Assessing Expectations Most Important to Restaurant Patrons: The Creation of the DinEX Scale. Journal of Foodservice Business Research, 13(4), 360-379. https://doi.org/10.1080/15378020.2010.524539

Asubonteng, P., Mccleary, K. J., \& Swan, J. E. (1996). SERVQUAL revisited: A critical review of service quality. Journal of Services Marketing, 10(6), 62-81. https://doi.org/10.1108/08876049610148602

Back, K.-J., \& Parks, S. C. (2003). A Brand Loyalty Model Involving Cognitive, Affective, and Conative Brand Loyalty and Customer Satisfaction. Journal of Hospitality \& Tourism Research, 27(4), 419-435. https://doi.org/10.1177/10963480030274003

Bitner, M. J. (1990). Evaluating Service Encounters: The Effects of Physical Surroundings and 
Employee Responses. Journal of Marketing. https://doi.org/10.2307/1251871

Bojanic, D. C., \& Drew Rosen, L. (1994). Measuring Service Quality in Restaurants: an Application of the Servqual Instrument. Hospitality Research Journal, 18(1), 3-14. https://doi.org/10.1177/109634809401800102

Bolton, R. N., \& Lemon, K. N. (1999). A Dynamic Model of Customers' Usage of Services: Usage as an Antecedent and Consequence of Satisfaction. Journal of Marketing Research, 36(2), 171. https://doi.org/10.2307/3152091

Bougoure, U.-S., \& Neu, M.-K. (2010). Service Quality in the Malaysian Fast Food Industry: An Examination Using DINESERV. Services Marketing Quarterly, 31(2), 194-212. https://doi.org/10.1080/15332961003604360

Brida, J. G., \& Coletti, P. (2012). Tourists' Intention of Returning to a Visited Destination: Cruise Ship Passengers in Cartagena de Indias, Colombia. Tourism in Marine Environments, 8(3), 127-143. https://doi.org/10.3727/154427312X13491835451412

Brown, T. J., Churchill, G. A., \& Peter, J. P. (1993). Improving the measurement of service quality. Journal of Retailing. https://doi.org/10.1016/S0022-4359(05)80006-5

Brunner, T. A., Stöcklin, M., \& Opwis, K. (2008). Satisfaction, image and loyalty: new versus experienced customers. European Journal of Marketing, 42(9/10), 1095-1105. https://doi.org/10.1108/03090560810891163

Chen, C.-T., Cheng, C.-C., \& Hsu, F.-S. (2015). GRSERV scale: an effective tool for measuring consumer perceptions of service quality in green restaurants. Total Quality Management \& Business Excellence, 26(3-4), 355-367. https://doi.org/10.1080/14783363.2013.832478

Choe, J. Y. (Jacey), \& Kim, S. (Sam). (2018). Effects of tourists' local food consumption value on attitude, food destination image, and behavioral intention. International Journal of Hospitality Management, 71, 1-10. https://doi.org/10.1016/j.ijhm.2017.11.007

Cronin, J. J., \& Taylor, S. A. (1992). Measuring Service Quality: A Reexamination and Extension. Journal of Marketing, 56(3), 55. https://doi.org/10.2307/1252296

Cronin, J. J., \& Taylor, S. a. (1994). SERVPERF versus SERVQUAL: and Reconciling of Service Measurement Perceptions Quality. Journal of Marketing, 58(1), 125-131. Retrieved from http://www.jstor.org/stable/1252256

Dabholkar, P. A., Shepherd, C. D., \& Thorpe, D. I. (2000). A comprehensive framework for service quality: An investigation of critical conceptual and measurement issues through a longitudinal study. Journal of Retailing. https://doi.org/10.1016/S0022-4359(00)00029-4

Dick, A. S., \& Basu, K. (1994). Customer loyalty: Toward an integrated conceptual framework. Journal of the Academy of Marketing Science. https://doi.org/10.1177/0092070394222001

Enrique Bigné, J., Mattila, A. S., \& Andreu, L. (2008). The impact of experiential consumption cognitions and emotions on behavioral intentions. Journal of Services Marketing, 22(4), 303-315. https://doi.org/10.1108/08876040810881704

Eren, R. (2019). Turkey's Food Image, Travelers' Revisit Intention and Tourist Expenditures. Anais Brasileiros de Estudos Turísticos - ABET, 9(1,2,3), 1-16. https://doi.org/https://doi.org/10.34019/2238-2925.2019.v9.27130

Fanelli, R. M., \& Di Nocera, A. (2018). Customer perceptions of Japanese foods in Italy. Journal of Ethnic Foods, 5(3), 167-176. https://doi.org/10.1016/j.jef.2018.07.001

Fick, G. R., \& Brent Ritchie, J. R. (1991). Measuring Service Quality in the Travel and Tourism Industry. Journal of Travel Research, 30(2), 2-9. https://doi.org/10.1177/004728759103000201

Fu, Y. Y., \& Parks, S. C. (2001). The Relationship between Restaurant Service Quality and Consumer Loyalty among the Elderly. Journal of Hospitality and Tourism Research. https://doi.org/10.1177/109634800102500306

Grönroos, C. (1984). A Service Quality Model and its Marketing Implications. European 
Journal of Marketing, 18(4), 36-44. https://doi.org/10.1108/EUM0000000004784

Han, H., Back, K. J., \& Barrett, B. (2009). Influencing factors on restaurant customers' revisit intention: The roles of emotions and switching barriers. International Journal of Hospitality Management. https://doi.org/10.1016/j.ijhm.2009.03.005

Han, H., \& Hyun, S. S. (2018). Role of motivations for luxury cruise traveling, satisfaction, and involvement in building traveler loyalty. International Journal of Hospitality Management, 70(July 2017), 75-84. https://doi.org/10.1016/j.ijhm.2017.10.024

Hansen, K. V. (2014). Development of SERVQUAL and DINESERV for Measuring Meal Experiences in Eating Establishments. Scandinavian Journal of Hospitality and Tourism, 14(2), 116-134. https://doi.org/10.1080/15022250.2014.886094

Heskett, J. L., Jones, T. O., Loveman, G. W. W., Earl Sasser, W., \& Schlesinger, L. A. (1994). Putting the service chain to work. Harvard Business Review, (April), 164-174.

Jacoby, J., \& Kyner, D. B. (1973). Brand Loyalty vs. Repeat Purchasing Behavior. Journal of Marketing Research, 10(1), 1. https://doi.org/10.2307/3149402

Kaya, O. (2018). Exploring the Satisfaction and Dissatisfaction Factors Derived from Food and Beverage Services of Thermal Hotels. Deturope, 10(3), 143-161.

Kim, H. J., McCahon, C., \& Miller, J. (2003). Assessing Service Quality in Korean CasualDining Restaurants Using DINESERV. Journal of Foodservice Business Research, 6(1), 67-86. https://doi.org/10.1300/J369v06n01_05

Kim, W. G., Ng, C. Y. N., \& Kim, Y. (2009). Influence of institutional DINESERV on customer satisfaction, return intention, and word-of-mouth. International Journal of Hospitality Management, 28(1), 10-17. https://doi.org/10.1016/j.ijhm.2008.03.005

Kim, W., Ok, C., \& Canter, D. D. (2010). Contingency variables for customer share of visits to full-service restaurant. International Journal of Hospitality Management, 29(1), 136-147. https://doi.org/10.1016/j.ijhm.2009.07.003

Kivela, J., Inbakaran, R., \& Reece, J. (1999). Consumer research in the restaurant environment, Part 1: A conceptual model of dining satisfaction and return patronage. International Journal of Contemporary Hospitality Management, 11(5), 205-222. https://doi.org/10.1108/09596119910272739

Kivela, J., Inbakaran, R., \& Reece, J. (2000). Consumer research in the restaurant environment. Part 3: analysis, findings and conclusions. International Journal of Contemporary Hospitality Management, 12(1), 13-30. https://doi.org/10.1108/09596110010304984

Kivela, J., Reece, J., \& Inbakaran, R. (1999). Consumer research in the restaurant environment. Part 2: Research design and analytical methods. International Journal of Contemporary Hospitality Management, 11(6), 269-286. https://doi.org/10.1108/09596119910281766

Knutson, B. J., Stevens, P., \& Patton, M. (1996). DINESERV: Journal of Hospitality \& Leisure Marketing, 3(2), 35-44. https://doi.org/10.1300/J150v03n02_04

Lee, Y. L., \& Hing, N. (1995). Measuring quality in restaurant operations: an application of the SERVQUAL instrument. International Journal of Hospitality Management, 14(3-4), 293-310. https://doi.org/10.1016/0278-4319(95)00037-2

Line, N. D., \& Runyan, R. C. (2012). Hospitality marketing research: Recent trends and future directions. International Journal of Hospitality Management. https://doi.org/10.1016/j.ijhm.2011.07.006

Liu, Y., \& Jang, S. (Shawn). (2009). The effects of dining atmospherics: An extended Mehrabian-Russell model. International Journal of Hospitality Management, 28(4), 494 503. https://doi.org/10.1016/j.ijhm.2009.01.002

Lőke, Z., Kovács, E., \& Bacsi, Z. (2018). Assessment Of Service Quality And Consumer Satisfaction In A Hungarian Spa. Deturope, 10(2), 124-146.

Loureiro, S. M. C. (2010). Satisfying and Delighting the Rural Tourists. Journal of Travel \& Tourism Marketing, 27(4), 396-408. https://doi.org/10.1080/10548408.2010.481580 
Marangoz, M., \& Akyıldız, M. (2007). Effects of Perceived Company Image and Customer Satisfaction on Customer Loyalty. Yönetim Bilimleri Dergisi, 5(1), 194-218.

Mattila, A. S. (2001). Emotional bonding and restaurant loyalty. Cornell Hotel and Restaurant Administration Quarterly, 42(6), 73-79. https://doi.org/10.1016/S0010-8804(01)81012-0

Nam, J. H., \& Lee, T. J. (2011). Foreign travelers' satisfaction with traditional Korean restaurants. International Journal of Hospitality Management, 30(4), 982-989. https://doi.org/10.1016/j.ijhm.2011.02.006

Namin, A. (2017). Revisiting customers' perception of service quality in fast food restaurants. Journal of Retailing and Consumer Services, 34, 70-81. https://doi.org/10.1016/j.jretconser.2016.09.008

Neal, W. D. (1999). Satisfaction is Nice, But Value Drives Loyalty. Marketing Research, 11(1), 21-23.

Oh, H. (2000). The Effect of Brand Class, Brand Awareness, and Price on Customer Value and Behavioral Intentions. Journal of Hospitality and Tourism Research. https://doi.org/10.1177/109634800002400202

Oliver, R. L. (1980). A Cognitive Model of the Antecedents and Consequences of Satisfaction Decisions. Journal of Marketing Research, 17(4), 460. https://doi.org/10.2307/3150499

Oliver, R. L. (1997). Satisfaction: A Behavioral Perspective on the Consumer. In McGraw-Hill series. https://doi.org/10.1139/h11-134

Oliver, R. L., \& Burke, R. R. (1999). Expectation Processes in Satisfaction Formation. Journal of Service Research, 1(3), 196-214. https://doi.org/10.1177/109467059913002

Ostrowski, P. L., O’Brien, T. V., \& Gordon, G. L. (1993). Service Quality and Customer Loyalty in the Commercial Airline Industry. Journal of Travel Research, 32(2), 16-24. https://doi.org/10.1177/004728759303200203

Parasuraman, A., Zeithaml, V. A., \& Berry, L. L. (1985). A Conceptual Model of Service Quality and Its Implications for Future Research. Journal of Marketing, 49(4), 41. https://doi.org/10.2307/1251430

Parasuraman, A., Zeithaml, V. A., \& Berry, L. L. (1988). SERVQUAL: A multiple- Item Scale for measuring consumer perceptions of service quality. Journal of Retailing, 64(1), 12 40.

Parasuraman, A., Zeithaml, V. A., \& Berry, L. L. (1991). Refinement and reassessment of the SERVQUAL instrument. Journal of Retailing, 67(4), 420-450.

Patterson, P. G. (2007). Demographic correlates of loyalty in a service context. Journal of Services Marketing, 21(2), 112-121. https://doi.org/10.1108/08876040710737877

Pizam, A., \& Ellis, T. (1999). Customer satisfaction and its measurement in hospitality enterprises. International Journal of Contemporary Hospitality Management, 11(7), 326339. https://doi.org/10.1108/09596119910293231

Pizam, A., \& Milman, A. (1993). Predicting satisfaction among first time visitors to a destination by using the expectancy disconfirmation theory. International Journal of Hospitality Management. https://doi.org/10.1016/0278-4319(93)90010-7

Pritchard, M. P., \& Howard, D. R. (1997). The Loyal Traveler: Examining a Typology of Service Patronage. Journal of Travel Research, 35(4), 2-10. https://doi.org/10.1177/004728759703500401

Qin, G., \& Prybutok, V. R. (2008). Determinants of Customer-Perceived Service Quality in Fast-Food Restaurants and Their Relationship to Customer Satisfaction and Behavioral Intentions. Quality Management Journal, 15(2), 35-50. https://doi.org/10.1080/10686967.2008.11918065

Qin, H., \& Prybutok, V. R. (2009). Service quality, customer satisfaction, and behavioral intentions in fast-food restaurants. International Journal of Quality and Service Sciences, 1(1), 78-95. https://doi.org/10.1108/17566690910945886 
Qin, H., Prybutok, V. R., \& Peak, D. A. (2009). Service quality in the USA and mainland China's fast-food restaurants. International Journal of Services and Standards, 5(4), 291. https://doi.org/10.1504/IJSS.2009.032174

Raajpoot, N. A. (2002). TANGSERV. Journal of Foodservice Business Research, 5(2), 109127. https://doi.org/10.1300/J369v05n02_08

Ramseook-Munhurrun, P. (2012). Perceived Service Quality in Restaurant Services: Evidence from Mauritius. International Journal of Management and Marketing Research, 5(3), 114.

Rosenbaum, M. S. (2006). Exploring the social supportive role of third places in consumers' lives. Journal of Service Research. https://doi.org/10.1177/1094670506289530

Ryu, K., \& (Shawn) Jang, S. (2008). DINESCAPE: A Scale for Customers' Perception of Dining Environments. Journal of Foodservice Business Research, 11(1), 2-22. https://doi.org/10.1080/15378020801926551

Ryu, K., \& Han, H. (2010). Influence of the Quality of Food, Service, and Physical Environment on Customer Satisfaction and Behavioral Intention in Quick-Casual Restaurants: Moderating Role of Perceived Price. Journal of Hospitality \& Tourism Research, 34(3), 310-329. https://doi.org/10.1177/1096348009350624

Ryu, K., \& Han, H. (2011). New or repeat customers: How does physical environment influence their restaurant experience? International Journal of Hospitality Management, 30(3), 599611. https://doi.org/10.1016/j.ijhm.2010.11.004

Seth, N., Deshmukh, S. G., \& Vrat, P. (2005). Service quality models: A review. In International Journal of Quality and Reliability Management (Vol. 22). https://doi.org/10.1108/02656710510625211

Shemwell, D. J., Yavas, U., \& Bilgin, Z. (1998). Customer-service provider relationships: an empirical test of a model of service quality, satisfaction and relationship-oriented outcomes. International Journal of Service Industry Management, 9(2), 155-168. https://doi.org/10.1108/09564239810210505

Stevens, P., Knutson, B., \& Patton, M. (1995). Dineserv: A Tool for Measuring Service Quality in Restaurants. Cornell Hotel and Restaurant Administration Quarterly, 36(2), 56-60. https://doi.org/10.1177/001088049503600226

TaghiPourian, M. J., \& Bakhsh, M. M. (2015). Loyalty: From Single-Stage Loyalty to FourStage Loyalty. International Journal of New Technology and Research, 1(6), 48-51.

Tan, Q., Oriade, A., \& Fallon, P. (2014). Service quality and customer satisfaction in Chinese fast food sector: A proposal for CFFRSERV. Advances in Hospitality and Tourism Research (AHTR), 2(1), 30-53.

Taylor, S. A., \& Baker, T. L. (1994). An assessment of the relationship between service quality and customer satisfaction in the formation of consumers' purchase intentions. Journal of Retailing. https://doi.org/10.1016/0022-4359(94)90013-2

Teas, R. K. (1993). Expectations, Performance Evaluation, and Consumers' Perceptions of Quality. Journal of Marketing, 57(4), 18. https://doi.org/10.2307/1252216

Tzeng, G.-H., \& Chang, H.-F. (2011). Applying Importance-Performance Analysis as a Service Quality Measure in Food Service Industry. Journal of Technology Management \& Innovation, 6(3), 106-115. https://doi.org/10.4067/S0718-27242011000300008

Weiss, R., Feinstein, A. H., \& Dalbor, M. (2004). Customer satisfaction of theme restaurant attributes and their influence on return intent. Journal of Foodservice Business Research. https://doi.org/10.1300/J369v07n01_03

Wirtz, J., \& Bateson, J. E. G. (1999). Consumer satisfaction with services: Integrating the environment perspective in services marketing into the traditional disconfirmation paradigm. Journal of Business Research. https://doi.org/10.1016/S0148-2963(97)001781 
Woodside, A. G., Frey, L. L., \& Daly, R. T. (1989). Linking service quality, customer satisfaction, and behavioral intention. Journal of Health Care Marketing, 9(4), 5-17. Retrieved from http://www.ncbi.nlm.nih.gov/pubmed/10304174

Yesiltas, M., Zorlu, O., Sop, S. A., \& Beydilli, E. T. (2014). The Effects of Service Quality on Customers' Tipping Behavior. International Journal of Academic Research in Business and Social Sciences, 4(8), 430-446. https://doi.org/10.6007/IJARBSS/v4-i8/1119

Yüksel, A., \& Yüksel, F. (2003). Measurement of tourist satisfaction with restaurant services: A segment-based approach. Journal of Vacation Marketing, 9(1), 52-68. https://doi.org/10.1177/135676670200900104

Zeithaml, V. A. (2000). Service quality, profitability, and the economic worth of customers: What we know and what we need to learn. Journal of the Academy of Marketing Science. https://doi.org/10.1177/0092070300281007 